\title{
ANALYSIS OF THE PRODUCTION PROCESSES AUTOMATION LEVEL IN POLAND
}

\begin{abstract}
The analysis of the production processes automation phenomenon in enterprises operating in Poland is the object of the presented chapter. The current state of automation of production processes has been also evaluated. The data presented in the chapter come from all types of analyses, reports and statistical data. The results of the analysis confirm that not only the production processes automation level of enterprises in Poland increases, but it also affects the flexibility of the production processes and the product quality improvement as well as financial effects of enterprises. In conclusion, authors underline that there are some barriers in the production processes automation implementing.
\end{abstract}

Keywords: automation, production process, enterprise

\section{Introduction}

Automation means creating within the business software such functionality that, without the need for human intervention, performs specific actions in response to specific situations. The factor that can initiate an automatic process can be an event, a certain resource level, or another indicator. Trend of the automation and manufacturing facilities robotics slowly circulates the whole world and accelerates the development of Industry 4.0 (FLORCZUK J. 2016).

In Poland there was created the Initiative for Polish Industry 4.0 that involves factors such as: passion, commitment to experience, challenges, effective solutions and the need to overcome barriers. Reflecting on the interests of Industry 4.0 concept of transformation and solutions is increasingly mass participation in the organization of conferences, workshops and presentations related to this subject. The main goal of the initiative is (CHOJNACKA U. 2016):

- generating support mechanisms for transformation,

- integration of the environment related to Polish Industry 4.0,

- evaluation of market needs and presentation of recommended actions.

In Poland, the initiative in its present form is not yet formalized, but it is gaining increasing interest. The industrialization of the economy and the continuous expansion

\footnotetext{
${ }^{1} \mathrm{PhD}$. Student, a member of Scientific Students Group Erasmus+Manager, Faculty of Management, Częstochowa University of Technology, Poland, e-mail: wojciechglin@gmail.com

$2 \mathrm{PhD}$. Ing., supervisor of Scientific Students Group Erasmus+Manager, Faculty of Management, Częstochowa University of Technology, Poland, e-mail: renatastasiak@wp.pl
} 
of the consumer market contribute to the initiative strengthening. Every local enterprise that is serious about its future knows that it should observe not only other enterprises surroundings. The enterprises attention should be focused not only on Polish, European but also on the world competitors.

Contemporary markets have no boundaries, so any enterprise equipped with modern tools, such as automated production lines, is unquestionably exploiting possibility of its extending. The world's industrial development needs make the global demand for a variety of the production automation means including industrial robots characterized by an upward trend. Therefore, the needs of the world robotics development cause that the global demand on the automation means is dynamic all over the world and it is independent of the pace of economic development.

\section{Types of automation levels}

In designing technological processes of the assembly, a particularly difficult task is to determine the optimal level of automation, i.e. time of the manually and automatically performed treatments related to the manufacturing process time. This factor significantly influences the production efficiency because it determines the labour intensity of the product manufacturing, the number of fitters and the type of equipment and its costs (ZENKIN A.S., ŁABUTINA O.W., KOZEŁŁO N.Ł. 2003).

The issue of categorization of automation levels is broadly described in the literature of the subject. Setting the level of automation it can be guided by the method developed by Kiev University of Technology and Design. This method is based on correlation-regression analysis using statistical data with the most modern parameters of technical and economic indicators of assembly processes. As numerical characteristics of the automation level of the technological process of assembly, the purpose is to use relative magnitude. Taking into account that the following elements are interrelated in the technological process: conditions of its production, type of product, type of equipment, production program, economic production indicators. Basic criterion combining studied parameters uses the reduction function, which in this case has been transformed into a form (ZENKIN A.S., LABUTINA O.W., KoZEŁŁO N.Ł. 2003):

$$
Z_{j}=(\delta+\beta) S N t_{j}+E_{H} \sum_{i=1}^{M} A_{i j} a_{i j}
$$

where:

$\mathrm{Z}_{\mathrm{j}}$ - variable part of the reduced expenditure [PLN/year],

$\mathrm{M}$ - number of operations for complete assembly of the product [items],

$\mathrm{i}$ - number of operations, 
$\mathrm{j}$ - number of variant,

$\delta=1,15$ - rate of wage with charges,

$\beta$ - bedspreads proportional to the total direct wages,

$\mathrm{S}$ - minute rate of the fitter [PLN],

$\mathrm{N}$ - annual production program of the product [items],

$\mathrm{E}_{\mathrm{H}}$ - normative efficiency factor of capital expenditure,

$t_{j}$ - labour effort of the assembly [min],

$\mathrm{A}_{\mathrm{ij}}$ - unit cost per $\mathrm{i}$-th operation,

$\mathrm{a}_{\mathrm{ij}}$ - the number of parallel operating devices.

The automation levels categories in accordance to Endsley Kabber categorization can be examined.

In 1999, Endsley and Kabber listed ten automation levels depending on the role a person or the machine. Ten levels of automation described by the authors are universal and do not apply only to the production environment. Table 18.1 below lists ten levels of automation according to Endsley and Kabber (KABER D.B., ENDSLEY M.R. 2004).

According to Endsley and Kabber, full automation of processes occurs when the machine itself monitors its work, and in the event of any problems it chooses itself, decides on its implementation and then implements it.

Endsley and Kabber's ten universal levels of automation have become the basis for defining dedicated levels of automation in the production processes.

According to DYNAMO project, the automation levels differ only in number but they are very close to each other. The common denominator for all defined levels of automation are the types of work that are used in these processes.

Table 2 presents levels of automation developed within the DYNAMO project.

Table 1. A summary of ten automation levels

\begin{tabular}{|c|c|c|c|c|}
\hline The automation levels & $\begin{array}{c}\text { Process } \\
\text { monitoring }\end{array}$ & $\begin{array}{c}\text { Generating } \\
\text { solutions }\end{array}$ & $\begin{array}{c}\text { The choice of } \\
\text { which solution } \\
\text { will be } \\
\text { implemented }\end{array}$ & $\begin{array}{c}\text { Implementation of } \\
\text { the solution }\end{array}$ \\
\hline $\begin{array}{c}\text { 1. Manual process } \\
\text { and control }\end{array}$ & Human & Human & Human & Human \\
\hline $\begin{array}{c}\text { 2. Supporting actions } \\
\text { by the machine }\end{array}$ & Human/Computer & Human & Human & Human/Computer \\
\hline $\begin{array}{c}\text { 3. Automatic deployment } \\
\text { of solutions by the } \\
\text { machine }\end{array}$ & Human/Computer & Human & Human & Computer \\
\hline $\begin{array}{c}\text { 4. Shared control } \\
\text { between man and machine }\end{array}$ & Human/Computer & Human/Computer & Human & Human/Computer \\
\hline $\begin{array}{c}\text { 5. Manpower assisted } \\
\text { by the machine in making } \\
\text { decisions }\end{array}$ & Human/Computer & Human/Computer & Human & Computer \\
\hline $\begin{array}{c}\text { 6. Shared decision- } \\
\text { making on the solution }\end{array}$ & Human/Computer & Human/Computer & Human/Computer & Computer \\
\hline
\end{tabular}




\begin{tabular}{|c|c|c|c|c|}
\hline $\begin{array}{c}\text { 7. Clearly defined (rigid) } \\
\text { system for decision } \\
\text { generation } \\
\text { and solution selection }\end{array}$ & Human/Computer & Computer & Human & Computer \\
\hline $\begin{array}{c}\text { 8. Automatic selection } \\
\text { of solutions }\end{array}$ & Human/Computer & Human/Computer & Computer & Computer \\
\hline $\begin{array}{c}\text { 9. Human control } \\
\text { over the process }\end{array}$ & Human/Computer & Computer & Computer & Computer \\
\hline 10. Full automation & Computer & Computer & Computer & Computer \\
\hline
\end{tabular}

Source: own elaboration based on KABER D.B., ENDSLEY M.R. 2004

Table 2. An automation levels in accordance to DYNAMO project

\begin{tabular}{|c|c|c|c|c|c|}
\hline \multirow{3}{*}{$\begin{array}{c}\text { Automation levels according } \\
\text { to Project DYNAMO }\end{array}$} & \multicolumn{4}{|c|}{ Three basic types of the work } & \multirow{3}{*}{ Process group } \\
\hline & \multicolumn{2}{|c|}{ Manual work } & \multirow[b]{2}{*}{$\begin{array}{c}\text { Machine } \\
\text { work }\end{array}$} & \multirow[b]{2}{*}{$\begin{array}{c}\text { Transport } \\
\text { of the material }\end{array}$} & \\
\hline & $\begin{array}{l}\text { Manual } \\
\text { loading }\end{array}$ & $\begin{array}{l}\text { Manual } \\
\text { loading }\end{array}$ & & & \\
\hline 1.Completely manual operations & YES & YES & NO & Manual & Manual process \\
\hline $\begin{array}{l}\text { 2. Manual operations using } \\
\text { simple tools } \\
\end{array}$ & YES & YES & NO & Manual & Manual process \\
\hline 3. Mixed operations & YES & YES & YES & Manual & $\begin{array}{c}\text { Manual and machine } \\
\text { process }\end{array}$ \\
\hline $\begin{array}{l}\text { 4. Operations with automatic } \\
\text { machine production cycle }\end{array}$ & YES & YES/NO & YES & Manual & $\begin{array}{l}\text { Manual and } \\
\text { machine process }\end{array}$ \\
\hline $\begin{array}{l}\text { 5. Automated machine cycle } \\
\text { requiring direct operator } \\
\text { supervision }\end{array}$ & NO & NO & YES & Manual & Automated process \\
\hline $\begin{array}{l}\text { 6. Automated machine operation } \\
\text { cycle with automatically } \\
\text { generated problem information }\end{array}$ & NO & NO & YES & Manual & Automated process \\
\hline $\begin{array}{l}\text { 7. Fully automated production } \\
\text { cells }\end{array}$ & NO & NO & YES & Automated & Automated process \\
\hline
\end{tabular}

Source: own elaboration based on MISIUREK B. 2014

Regardless of the number of automation levels there are three groups of processes: manual process, mixed process, automated process. The levels of automation for production processes depend on the nature of the underlying types of work that are used in the production of the final product in the process and the process group.

According to MISIUREK B. (2014), the direct human work with the machine ends in the third stage of automation, and since the fourth stage of automation the work of an operator operating such a machine is reduced to supervising the machine. Described levels of automation confirm that direct human work with the machine ends at the third automation stage, and that from the fourth level of automation the machine operator is only supervised.

Considering the levels of automation, drivers of change in the industry and the economy should be taken into account, such as: a technological progress, customer expectations, new patterns of individual consumption, and geopolitical changes. 


\section{The automation level of enterprises in Poland}

Today innovations and new technologies are the most important products and services on the list of every creative entrepreneur who seeks to increase productivity, quality and competitiveness. The possibilities of new solutions, devices are constantly increasing.

There is increasing demand for modern IT tools, automation, robotics that requires the use of a variety of analyses, statistics, comparisons, evaluations of automation and robotics. The most automated industries include: automotive industry, chemical industry, rubber industry, plastic industry, machine industry and metal and electronic industry.

Polish production companies are increasingly willing to reach for solutions in the field of automation and information technology. Astor enterprise conducted a study in the third quarter of 2015 among 100 manufacturing business representatives that $91 \%$ declare partial or full production automation.

Meanwhile, in 2014, only $80 \%$ of respondents responded the same way. Most fully automated companies are high-income companies. There are only $33 \%$ of the surveyed Polish enterprises admitted that they were not computerized. This means that as many as $2 / 3$ of organizations use software to support the management of a plant. These are more and more often MES systems. Figure 1 shows what information systems are used by enterprises in Poland.

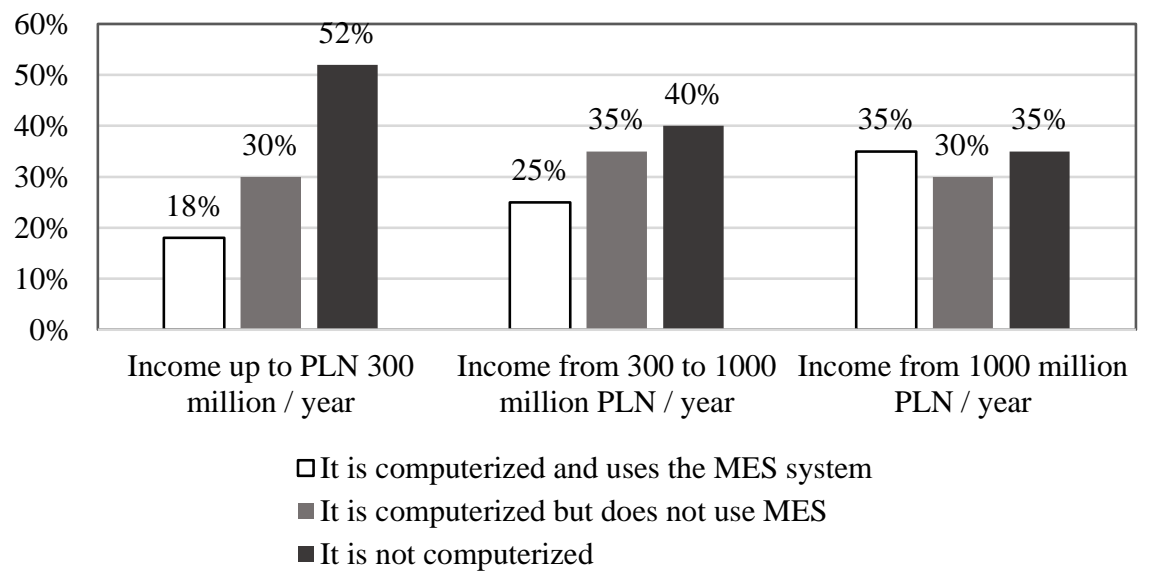

Fig. 1. IT systems used by enterprises in Poland in 2015.

Source: own elaboration based on WHITEPAPER A.2014 
Astor in this report also included information about level of automation in enterprises in Poland in 2013 and in 2015. Figure 2 shows these data.

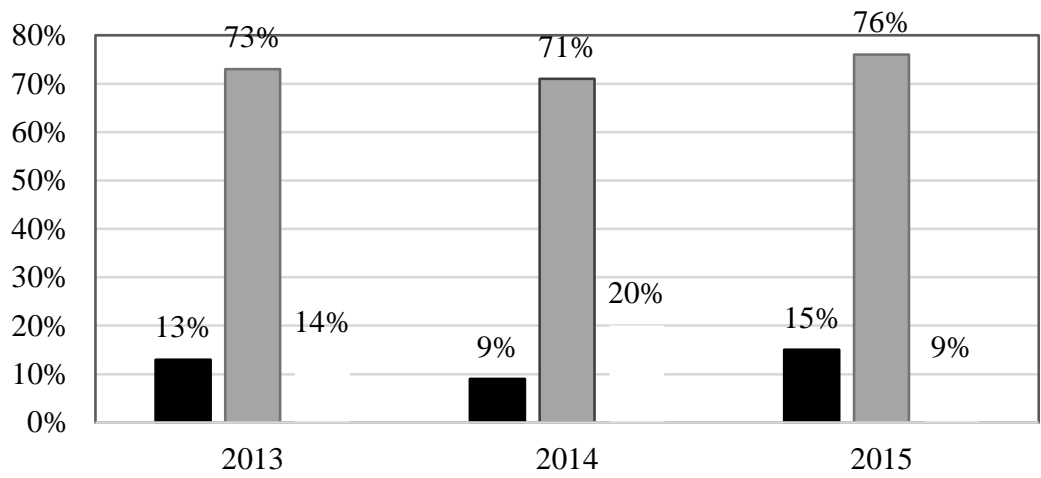

- Fully automated $\quad \square$ Partly automated Not automated at all

Fig. 2. The degree of automated enterprises in Poland in 2013-2015.

Source: own elaboration based on WHITEPAPER A.2014

Astor's report presents tendency for downtimes monitoring. Figure 3 shows enterprises that have registered downtimes.

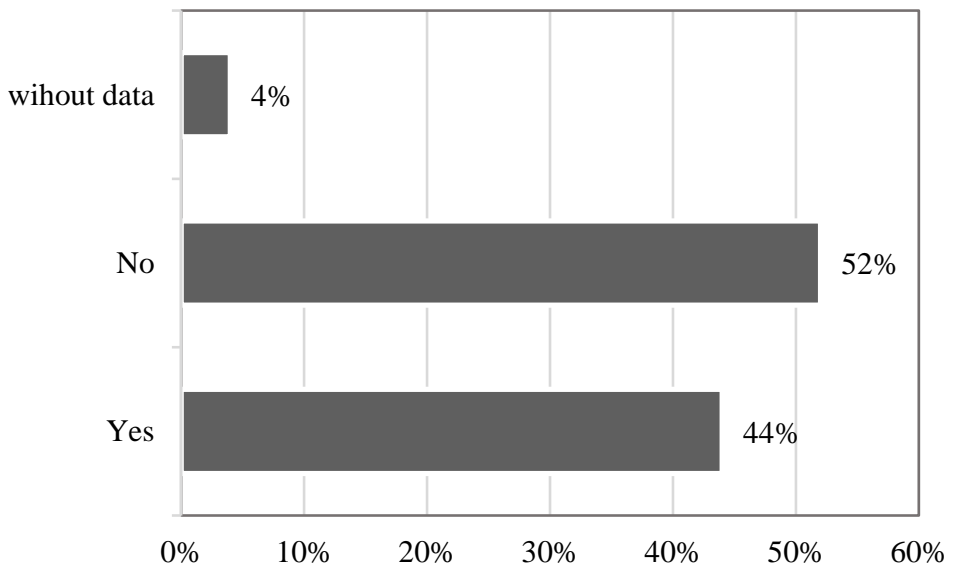

Fig. 3. Percentage of companies that registered downtimes in 2015.

Source: own elaboration based on WHITEPAPER A.2014

Companies are increasingly aware of the dangers of micro-machines. Meanwhile, as indicated by the experts, the level of machine availability exposed to downtimes 
could fall by a dozen or even several dozen percent. FROST \& SULLIVAN awarded the ASTOR Award for Best Industrial Automation Advisor in 2016.

In 2014, most of the means of automating production processes in the industry were owned by industrial processing companies. Almost all machined centres, numerically controlled laser machines and industrial robots and manipulators have been installed in companies in the industry. Compared to the year 2013, the number of types of automation has increased in the industrial processing sector and the most machining centres.

Analysing the level of automation of the enterprises cannot ignore one of main components of automated production - robots. The development needs of the global industry cause that global demand for industrial robots has growing tendency. However, it is subject to some fluctuations, which are responsible for changes in the economy.

According to the International Federation of Robotic (IFR), more than 178,000 industrial robots were sold in 2013, representing a 12\% increase compared to 2012 . Sales of industrial robots by industry are shown in Figure 4.

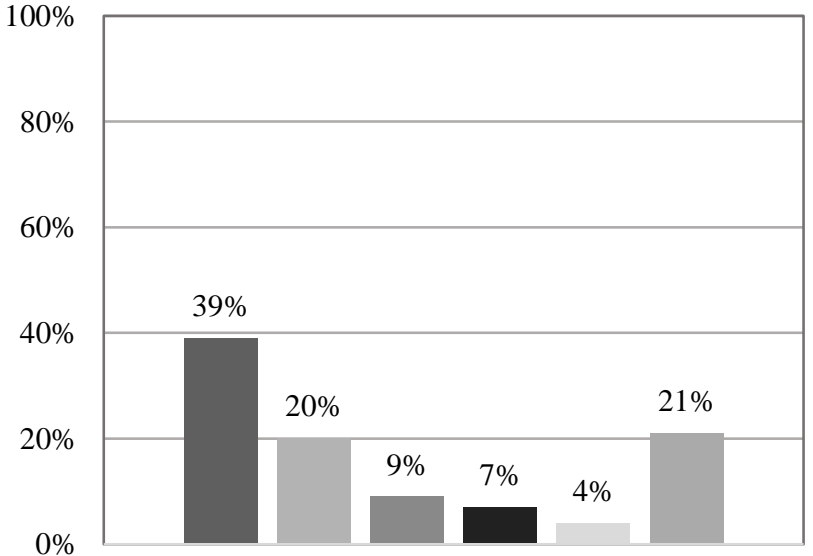

Industry robots
Automotive industry

Electrical and electronic equipment industry

- Machine industry

- Production of rubber and plastic materials Food industry

Fig. 4. Sale level of robots by industry in 2013.

Source: own elaboration based on ŁAPIŃSKI K., PETERLIK M., WYŻNIKIEWICZ B. 2015

According to the International Federation of Robotics, the average robotic density in the world economy is estimated to 62 industrial robots per 10 thousand of industry employees.

In Poland, in terms of installed industrial robots, it differs significantly from the average. Industrial divisions with the largest number of industrial robots in Poland are: 
automotive industry, manufacturing of rubber and plastics products, production of metal products, production of electrical equipment, production of computers and electronic products, production of the machinery and equipment, metal production, production of non-metallic raw materials, furniture production, production of foodstuffs and the wood and cork production.

As already mentioned enterprises, they carry out in their plants robotics of the production guided by specific economic premise. So they expect a number of effects, which will generally improve the situation of the company.

The research conducted by IBnGR in 2013 and 2015 shows that companies that have implemented industrial robots in the majority of cases have recorded measurable economic benefits.

The effects of the production automation can be divided into: financial, market, production plant, for staff. Figure 5 and Figure 6 present financial effects of the production processes automation for enterprises in Poland in 2013 and 2015.

Figure 7 and figure 8 presents market effects of the production automation in enterprises in Poland in 2013 and 2015.

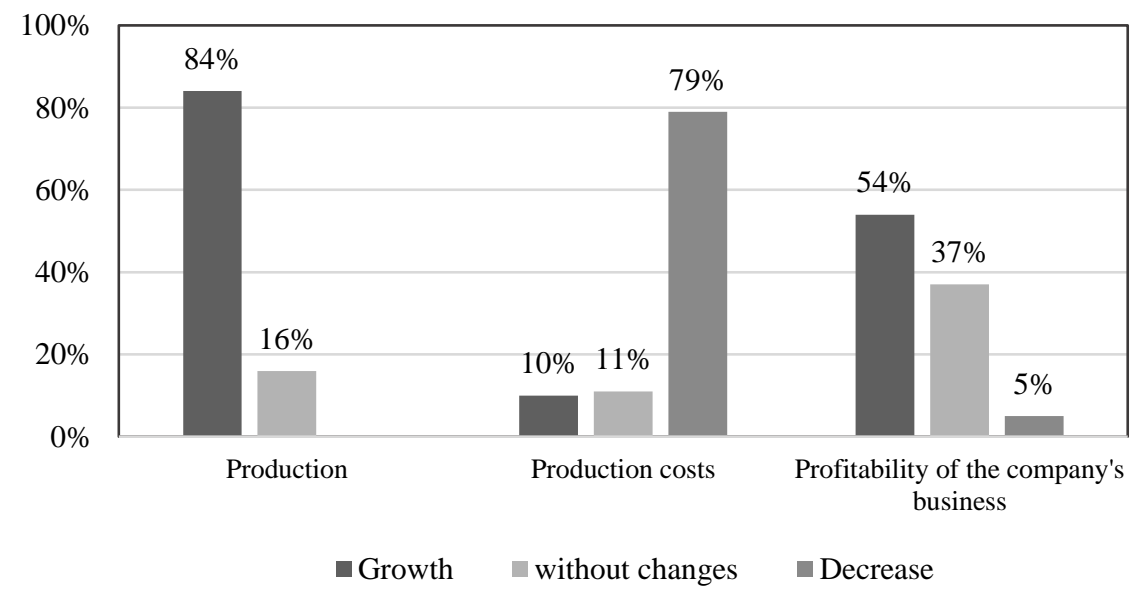

Fig. 5. Financial results for the automated enterprises in Poland in 2013.

Source: own elaboration based on IBnGR research 


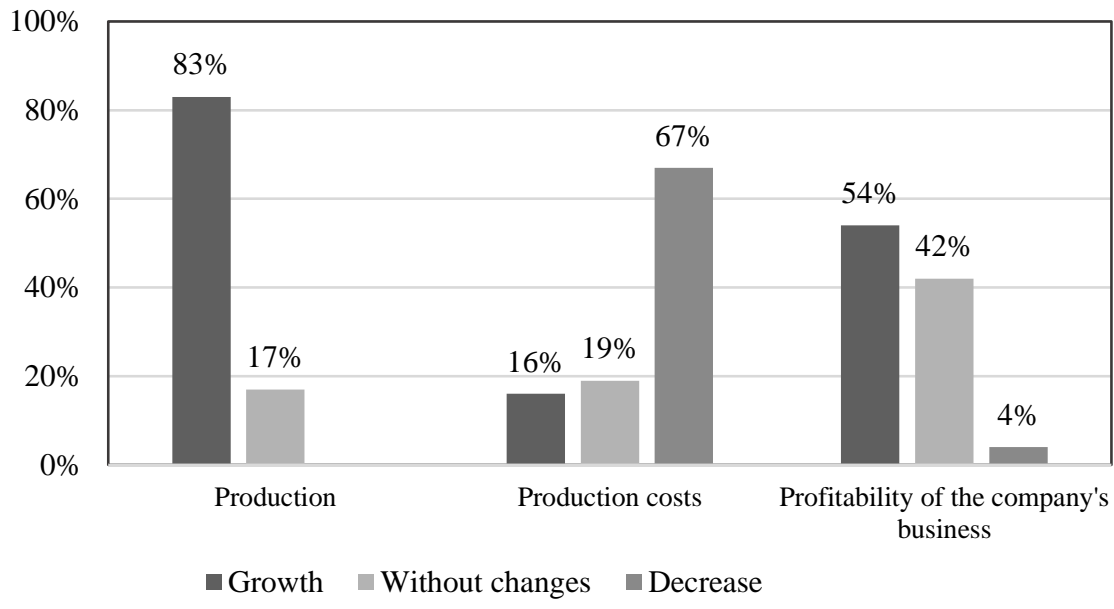

Fig. 6. Financial results for the automated enterprises in Poland in 2013.

Source: own elaboration based on IBnGR research

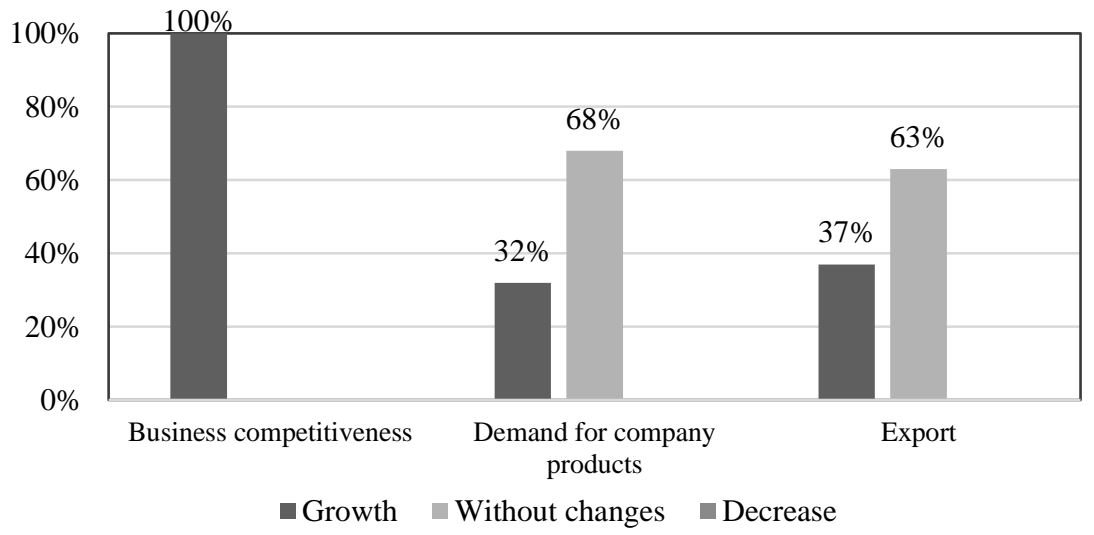

Fig. 7. Market results for the automated enterprises in Poland in 2013.

Source: own elaboration based on IBnGR research 


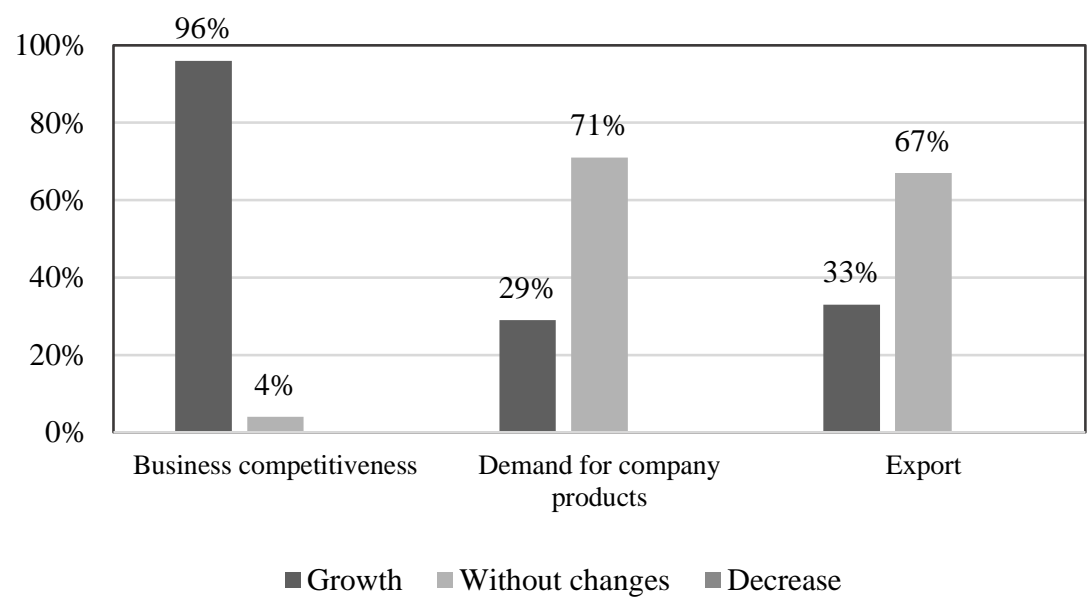

Fig. 8. Market results for the automated enterprises in Poland in 2015.

Source: own elaboration based on IBnGR research

Figure 9 and Figure 10 present production effects for enterprises in Poland in 2013 and 2015.

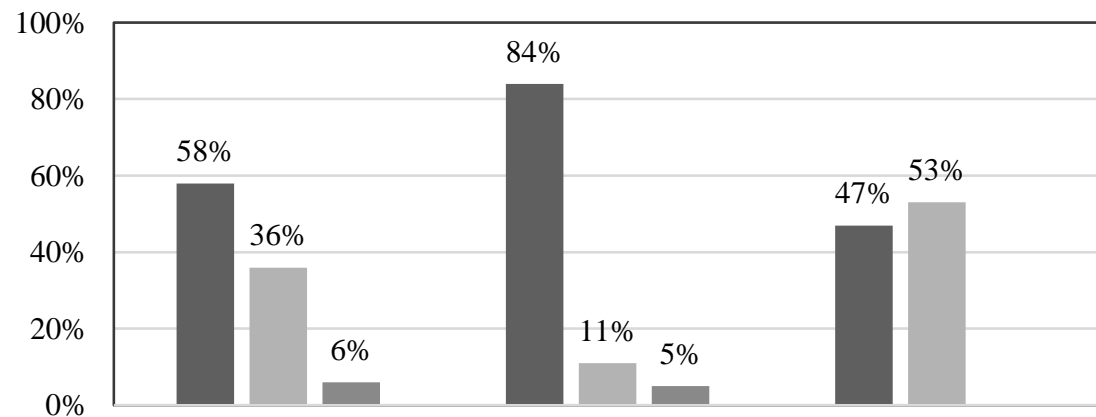

Flexibility of the production Overall quality of products Technological advancement line of products

Growth $\quad$ Without changes $\quad$ Decrease

Fig. 9. Production results for the automated enterprises in Poland in 2013.

Source: own elaboration based on IBnGR research 


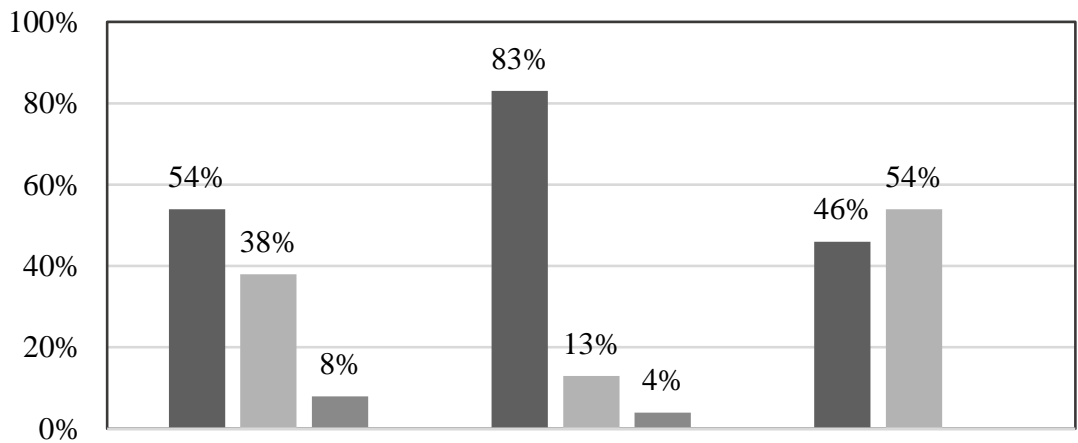

Flexibility of the production Overall quality of products Technological advancement line of products

Growth Without changes $\square$ Decrease

Fig. 10. Production results for the automated enterprises in Poland in 2015. Source: own elaboration based on IBnGR research

Figure 11 and Figure 12 present effects of workers for the automated enterprises in 2013 and 2015.

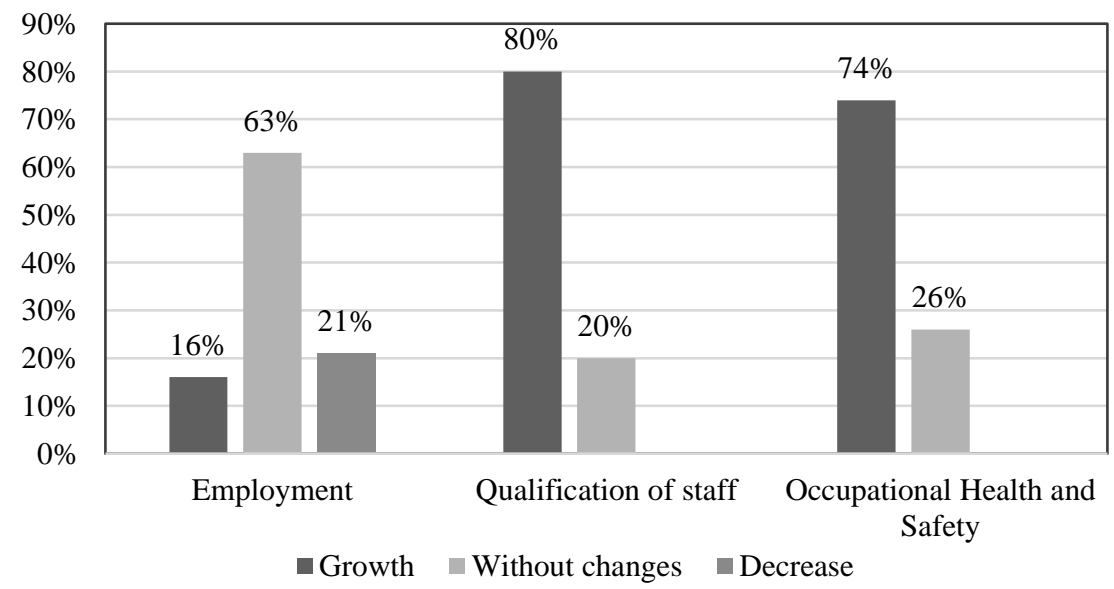

Fig. 11. Workers results for the automated enterprises in Poland in 2013.

Source: own elaboration based on IBnGR research 


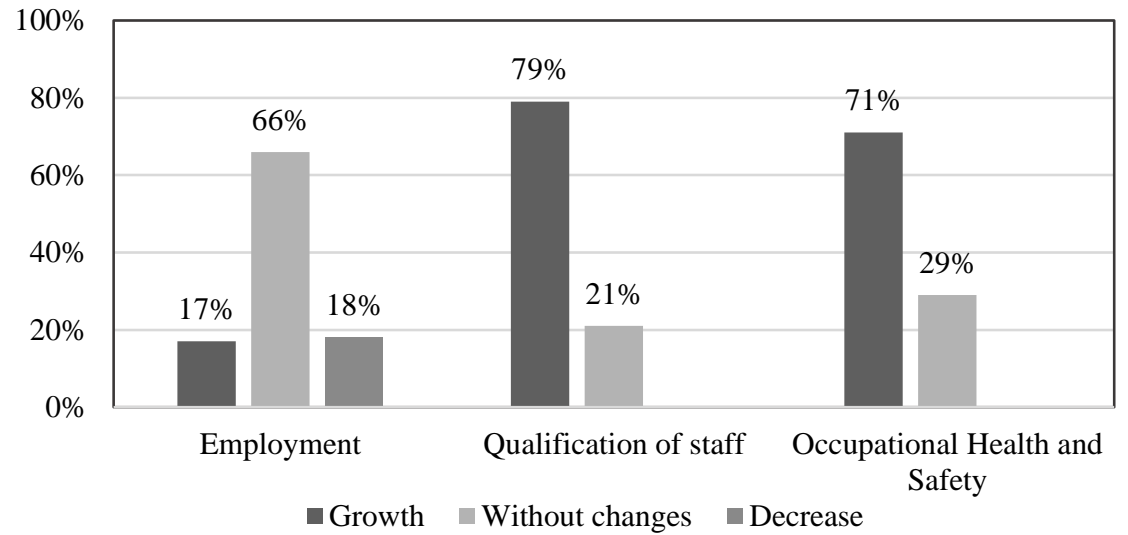

Fig. 12. Workers results for the automated enterprises in Poland in 2015.

Source: own elaboration based on IBnGR research

These results clearly show that running a robotic plant means increasing productivity. The IBnGR study shows that companies that did not invest in Figure 13 show the main factors for the lack of production robots in 2013 and 2015.

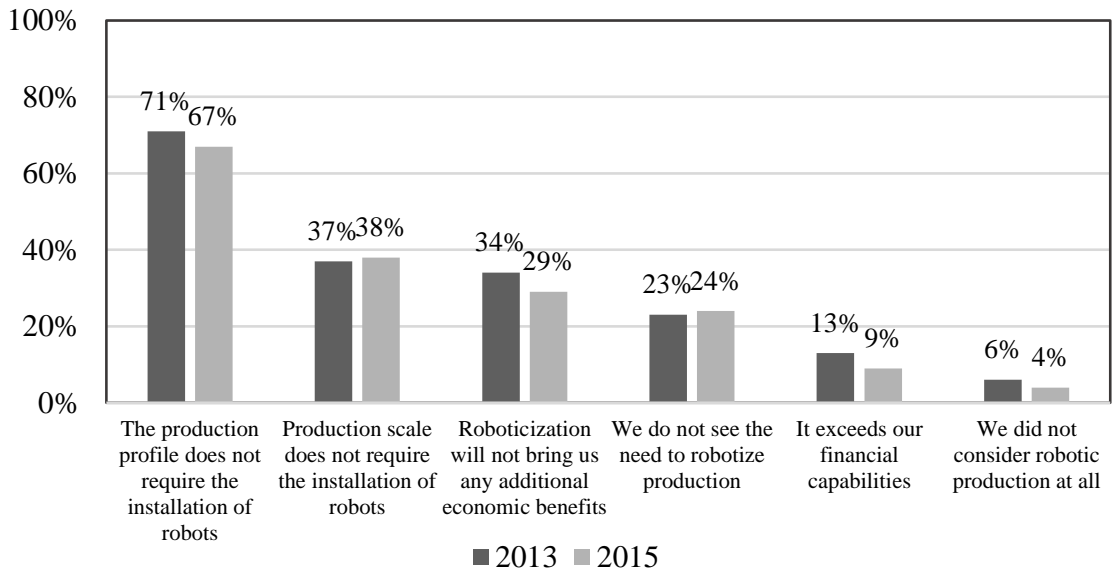

Fig. 13. Key factors for lack of robotization in Poland in 2013 and 2015.

Source: own elaboration based on IBnGR research

As indicated by research carried out by IBnGR, Polish entrepreneurs are more favourably than in 2013 for the production automation. First of all, fewer enterprises indicates their production profile as a major reason for the lack of automation. This may mean that the general knowledge of automation and robotics and the benefits that it can bring is increasing. 


\section{Conclusions}

Automation of manufacturing processes is treated by Polish manufacturers as an indispensable element in the development of the company. Increasing requirements in terms of production efficiency, product quality and safety processes pose a big challenge for companies. New production technologies and automation applications for both industrial and commercial applications, are increasing their use, especially in the aerospace, industrial, automotive sector of health care. Although the most popular technique still enjoy more efficient in terms of cost, that offer a return on investment at a good level and more attention is paid to processes that can reduce production time and energy consumption.

\section{Bibliography}

1. ChOJnaCKa U. 2016. Czas na (r)ewolucyjne przyspieszenie w polskim Przemyśle 4.0. Automatyka 10/2016. S. 26-29

2. GŁÓWNy URZĄD STATYSTYCZNY 2015. Działalność innowacyjna przedsiębiorstw w latach 2012-2014. Warszawa.

3. GŁÓWNY URZĄD STATYSTYCZNY 2015. Nauka i technika w 2014r. Science and technologa in 2014. Warszawa.

4. HonCZARENKo J. 2006. Robotyzacja i automatyzacja lekiem na globalizacje produkcji? Wydawnictwo Instytut Mechanizacji Budownictwa i Górnictwa Skalnego. Warszawa.

5. FLORCZUK J. 2016. Automatyzacja procesów sposobem na zwiększenie efektywności ERP. Portal wiedzy menadżerskiej. http://blog.macrologic.pl/2298-automatyzacja-procesowsposobem-na-zwiekszenie-efektywnosci-erp.

6. Kaber D.B., EndSLEy M.R. 2004. The effects of level of automation and adaptive automation on human performance, situation awareness and workload in a dynamic control task. Theoretical Issues in Ergonomics Science. No 1/3, pp. 113-153.

7. ŁAPIŃSKI K., PETERLIK M., WYŻNIKIEWICZ B. 2015. Wpływ robotyzacji na konkurencyjność polskich przedsiębiorstw.

8. MisIUREK B. 2014. Metodyka standaryzacji autonomicznych procesów eksploatacyjnych zorientowana na poprawę efektywności maszyn zautomatyzowanych. Wrocław, pp. 34.

9. WhITEPAPER A. 2014. W jakiej technologie inwestuja firmy produkcyjne w Polsce? Astor. Kraków.

10. ZENKIN A.S., ŁaBUTINA O.W., KozeŁŁo N.Ł. 2003. Wyznaczanie optymalnego poziomu automatyzacji procesów technologicznych montażu wyrobu. Technologia i automatyzacja montażu. No 2 . 